\title{
THE BUKAVU CONFERENCE
}

\author{
By Captain Keith Caldweld
}

(The third international conference for the protection of African fauna and flora was held at Bukavu, in the Belgian Congo, from 26th to 31st October, 1953. The United Kingdom delegation was led by Captain Keith Caldwell. The article below is reprinted by permission of the Editor of The Field.)

A convention for the protection of the fauna and flora of Africa was drawn up at a conference held in London in 1933 and was ratified by almost all the Powers with possessions in Africa. Another conference took place about five years later, which recommended certain alterations in the convention, but owing to the war these were never carried into effect. Since then it has been obvious that the time for further action was overdue.

The newest conference, held by invitation of the Belgian Government, was well attended by delegations from Belgium, Egypt, France, Italy, Portugal, Southern Rhodesia, the United Kingdom, and the Union of South Africa, and observers came from Denmark, the Anglo-Egyptian Sudan, and the U.S.A., as well as from a number of " organismes" (as the official list had it) designated by initials-e.g., I.N.E.A.C., I.R.S.A.C., C.I.P.Q., I.P. or B.C., I.B.E.D., and others. What they all stand for I am not entirely certain, but I know they are very learned bodies, whose representatives contributed greatly to our deliberations.

The United Kingdom delegation was a strong one, and included representatives from nearly all the British colonial territories in Africa. In addition we had the advantage of having held a preliminary conference of our own in Tanganyika last April, and thus had been able to formulate certain resolutions and decide on our action.

One of the features of the conference, in happy contrast to so many international conferences these days, was the obvious desire of all delegates to be helpful and to reach agreement. In particular I would mention the French delegation, brilliantly led by M. Omer Sarraut. They combined complete mastery of their subject with firmness in debate and determination to co-operate in every way.

Although the conference was concerned with the protection of plant as well as animal life, interest and attention were naturally concentrated chiefly on the conservation of game. It has long been obvious that the greatest threat to the African wild fauna is slaughter by natives, especially when they kill for profit. The 
value of meat is, in places, 10 times what it was before the war, and demand creates supply.

Certain governments have shown great reluctance to take any steps to put an end to, or even to curtail seriously, what they have held to be native hunting " rights". But an admirable and most interesting paper was presented by the Belgian delegation showing that the so-called "rights" were in fact trivial and that, before the advent of the European, they were strictly limited and closely defined.

In general, hunting was only permitted by special authorization of the local chief, who said what might be hunted and where ; moreover the animal, when killed, could only be cut up in the presence of the chief or his representative. Needless to say the chief took the best of the meat and the rest was distributed according to tribal custom. After the demands of the hunter's parents, wives, brothers, sisters, uncles, girl friends and others, to say nothing of the folk who helped in the chase, had been satisfied, the hunter was lucky if he got a bit of the intestines and perhaps the heart. Thus native custom eliminated, in a very sure way, the profit motive and prevented any undue diminution of the game.

I am glad to say that all the delegates agreed that some action was necessary in the interest of the Africans themselves, and recommended that, since fauna was an important food supply, particularly in tsetse fly areas, governments should take all possible steps to restrict the excessive destruction of wild animals whether for meat, profit, or trophies. It was agreed further that the convention of 1933 should be amended so that the sale, purchase, barter, or exchange of trophies or meat be regulated and, where possible, prohibited unless with proper permission. A further recommendation was made that the contracting governments should take powers to proscribe the movement of large quantities of game meat. Action on these lines has been of great value in Kenya in putting the biltong peddler out of business.

It was recognized that the enforcement of regulations against sales of trophies and meat can at best be only partially successful, and a resolution was passed drawing attention to the great importance of propaganda, and the education of people of all ages and classes in the conservation of wild life.

Something on these lines is essential, and as time goes on I hope that these methods will become more and more effective. But some years ago I gave what I hoped was an impassioned address on the benefits of national parks, to a native audience 
that seemed intelligent and interested. I drew attention to the great success of the Nairobi National Park at our doorstep and finally asked for " any questions".

I promptly got one. "Sir, why are we not allowed to kill and eat the guinea fowl in the park? Good food for the people is being wasted." I was defeated.

One of the most important acts of the 1933 convention was to place certain of the rarer animals in classes $\mathbf{A}$ and $\mathbf{B}$. Those in class $\mathbf{A}$ were to be protected completely and those in class B were only to be hunted, killed or captured, under special licence, i.e. a licence other than an ordinary game licence. The 1938 conference drew attention to the fact that some animals were rare over most of their range but reasonably common in a few places. In theory such animals should, of course, be protected locally, but there is no getting away from it that putting animals on an international list brings considerable moral pressure to bear.

The latest conference recommended the creation of a new class, to be called class $\mathrm{C}$, in which should be placed those species which, in most places but not everywhere, "stand in need of the same protection as would be afforded by their inclusion in class B."

There has always been a tendency for certain folk to recommend strange and little known mammals for inclusion in class $\mathbf{A}$. As an example, the 1938 conference was most anxious that a species of the giant cane rat (Lophiomys Milne Edwards) be put on the list. I have never been able to fathom the point of this sort of recommendation. The rat is, admittedly, eaten by the Wa'Nderobo, and I am prepared to believe that it is " in short supply", but it certainly is not, so far as we know, in any danger of extermination. Putting it on list $\mathbf{A}$ would, I fear, have no effect whatever on the $\mathbf{W a}$ 'Nderobo, who have never heard of the list and whose attitude toward it, if they had, would be less than co-operative.

I am glad to say that now a definite recommendation has been adopted that no species shall be included in any of the classes unless such action" will provide a practical and effective means of protection".

No great alterations were made to class A (animals requiring maximum protection) except that the plains gorilla (G.g. gorilla) was put back, at the request of the French delegation, to class B. It appears that these gorillas are increasing in numbers in West Africa and causing considerable damage. The mountain gorilla ( $G$. beringei) remains in class $A$. The giant tortoises of the East 
African islands and the small boa (killed for its skin) were added to class $\mathbf{A}$, as were the blind fishes of the East African and Madagascar caves. If you ask how the inclusion of these fish fits in with the criteria referred to above, the answer is that it does not. But a conference would be wholly unrepresentative of a congeries of nationalities-and very dull-if it were always entirely logical.

Class B (animals that may be shot under special licence) was enlarged by the inclusion, amongst others, of the addax, the white oryx, and the Grevy zebra.

Class $\mathrm{C}$ is lengthy and includes leopard, cheetah, situtunga, bongo, impala, greater and lesser kudu, Hunter's antelope, roan, sable and hippopotamus. The leopard, on account of the profit to be made out of its skin and its value as a predator of such vermin as baboons, would have been put in class B but for objections raised by one or two territories. It was accordingly relegated to $\mathbf{C}$, but it is hoped that most of the countries where it is found, but where it is becoming very scarce, will put it in class $B$ on their own initiative.

Problems of control were dealt with by a special sub-committee. This body made a number of recommendations, of which the principal were: (a) That as a matter of urgency, research should be conducted into wild animal diseases and that such research should precede major control operations; (b) That control should be regarded as an essential aspect of conservation and entrusted to adequately trained personnel ; $(c)$ That further experiments should be carried out on the erection of artificial barriers to limit the movements of wild animals.

These recommendations were adopted by the conference, which also declared against automatic weapons and finally urged the creation in all territories of a competent and adequately staffed game department.

What was agreed and recommended may not seem much, but it represents a real advance both in letter and in spirit. It remains to be seen if these resolutions will be accepted, and above all implemented, by the governments concerned. Then we can hope that the wild fauna of Africa, outside as well as within the national parks, may be saved for posterity. 